doi: 10.15503.onis2021.15.29

\title{
ROLA TRENERA W PRZYGOTOWANIU WSPÓŁCZESNEJ MŁODZIEŻY DO PROFESJONALNEGO UPRAWIANIA PILKI NOŻNEJ
}

\author{
Grzegorz Koprukowiak \\ Akademia Wychowania Fizycznego im. Józefa Piłsudskiego w Warszawie \\ ul. Marymoncka 34, 00-809 Warszawa \\ E-mail: grzegorz.koprukowiak@awf.edu.pl \\ ORCID: https://orcid.org/0000-0002-8072-5161
}

\begin{abstract}
Abstrakt
Teza. Niniejszy artykuł jest próbą ukazania roli trenera w przygotowaniu współczesnej młodzieży do profesjonalnego uprawiania piłki nożnej. Gra w piłę nożną jest bowiem jedną z preferowanych form aktywności fizycznej szczególnie wśród dzieci i młodzieży. Wielu młodych ludzi, rozwijając swój talent piłkarski, podejmuje się przejścia przez złożony i długotrwały proces selekcji, mający na celu uformowanie piłkarza zawodowego. Aby proces ten przebiegał właściwie, istotna jest osoba trenera.

Omówione koncepcje. W celu przybliżenia jego wyjątkowej funkcji w formowaniu zawodników, Autor tekstu zarysował uwarunkowania społeczno-kulturowe wpływające na specyfikę zawodu piłkarza. W świetle tych zmian zaprezentowana zostaje również funkcja trenera. Autor przybliża skomplikowany i wielowymiarowy proces formowania i selekcji graczy, którego przeprowadzenie spoczywa na trenerze wspieranym przez odpowiednie instytucje oraz piłkarskich skautów.

Wyniki i wnioski. Autor wyszczególnia cechy, jakimi powinien dysponować trener, by wesprzeć zawodników w tym procesie. Jego rola nie ogranicza się bowiem do formacji technicznej zawodnika - trener jest również wychowawcą. Z tego względu powinien on posiaść wiedzę z zakresu pedagogiki i psychologii sportu, jak również socjologii kultury fizycznej.

Wartość poznawcza. Najwyższą wartość poznawczą niniejszego artykułu stanowi ukazanie przez Autora znaczenia nauk humanistycznych w przygotowaniu współczesnej młodzieży do profesjonalnego uprawiania piłki nożnej. Wskazane przez Autora założenia, wynikające z socjologii kultury fizycznej oraz pedagogiki, wzajemnie uzupełniają się z założeniami teorii sportu i metodyki treningu piłkarskiego. Treści przedstawione $\mathrm{w}$ artykule,znajdują swoje praktyczne zastosowanie $\mathrm{w}$ najnowszych koncepcjach rozwoju talentu sportowego, głównie w zachodnioeuropejskich klubach piłkarskich.
\end{abstract}

Słowa kluczowe: talent, pedagogika sportu, socjologia kultury fizycznej, psychologia sportu, selekcja, piłka nożna, skauting, trener.

The role of the coach in preparing modern youth for professional football

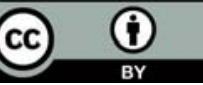

Ogrody Nauk i Sztuk nR 2021 (11) 


\begin{abstract}
Aim. This article is an attempt to show the role of a coach in preparing modern young people for professional football. The game of football is one of the preferred forms of physical activity, especially among children and adolescents. When developing their football talent, many young people undertake the complex and lengthy dissection process to become a professional footballer. In order for this process to proceed properly, the personage of the coach is essential.

Concept. In order to present the exceptional function of the coach in the formation of players, the author outlines the socio-cultural conditions influencing the specificity of the profession of a footballer. The function of the coach is also presented in the light of these changes. The author also introduces the complicated and multidimensional process of developing and selecting players, which is performed by the coach, supported by appropriate institutions and football scouts.

Results and conclusion. The author lists the characteristics a coach should possess to support the players in this process. His role is not limited to the technical development of the player - the coach is also an educator. For this reason, he should possess knowledge in the field of pedagogy and the psychology of sport, as well as the sociology of physical culture.

Cognitive value. The greatest cognitive value of this article is the fact that the author shows the importance of the humanities in the preparation of young people for professional football. The assumptions indicated by the author, resulting from the sociology of physical culture and pedagogy, complement the assumptions of the theory of sport and the methodology of football training. The content presented in the article finds its practical application in the latest concepts of the development of sports talent, mainly in Western European football clubs.

Key words: Talent, sports pedagogy, sociology of physical culture, sports psychology, selection, football, scouting, coach.
\end{abstract}

\title{
WPROWADZENIE
}

We współczesnym społeczeństwie dochodzi do pogłębiających się zmian w sposobie jego funkcjonowania w różnych dziedzinach życia. Źródłem tych zmian jest między innymi rozwój cywilizacyjny, wpływający wielowymiarowo na charakter i specyfikę nowych pokoleń. Współczesny charakter pracy zarobkowej to jedna z przestrzeni, $\mathrm{w}$ których te zmiany są zauważalne. Styl pracy jest bowiem uwarunkowany przemianami społecznymi i gospodarczymi, które przekładają się również na życie osobiste.

W świetle tych przemian, zupełnie nowe znaczenie zyskuje uczestnictwo w kulturze fizycznej. Obecnie staje się ono jednym ze sposobów aktywnego wypoczynku dla osób dorosłych, jak również dużej grupy dzieci i młodzieży. Jedną z preferowanych aktywności sportowych jest piłka nożna, która często staje się dla młodych ludzi nie tylko formą aktywnego wypoczynku, lecz sposobem na realizację marzeń o przyszłej karierze zawodniczej - na miarę swoich piłkarskich autorytetów ze światowej czołówki. Aspiracje te przekładają się na wieloletni proces, podczas którego młody zawodnik obok doskonalenia swoich umiejętności sportowych, uczestniczy w procesie selekcji. Selekcja ta pozwala na wyróżnienie szczególnie utalentowanych jednostek, posiadających wyjątkowe predyspozycje do profesjonalnego uprawiania sportu. Kształcenie 
umiejętności sportowych młodego zawodnika jest równocześnie procesem pedagogicznym, w którym szczególną rolę odgrywa trener.

Celem niniejszego artykułu jest zaprezentowanie znaczenia pracy trenera $\mathrm{w}$ procesie formacyjno-wychowawczym adeptów. W pierwszej kolejności zostanie zarysowane charakterystyczne dla obecnych czasów tło społeczne, w które wpisuje się specyfika zawodu profesjonalnego gracza piłki nożnej. W tekście przedstawiono wyzwania stojące przed środowiskiem trenerskim, mające na celu właściwe przygotowanie zawodnika do profesjonalnego sportu. W dalszej kolejności przedstawiony będzie proces dojrzewania młodego gracza do zawodowego uprawiania dyscypliny. W ostatniej części artykułu - w świetle powyższych zagadnień - omówiona zostanie rola współczesnego trenera. Jest on bowiem nie tylko wychowawca, mentorem i opiekunem w procesie podnoszenia kompetencji umiejętności piłkarskich, oraz wypracowaniu właściwych postaw moralnych u młodego zawodnika.

\section{SPORT ZAWODOWY W KONTEKŚCIE WSPÓŁCZESNYCH UWARUNKOWAŃ SPOŁECZNYCH}

Piotr Rymarczyk (2019), określając charakterystykę nowych społeczeństw, przedstawia je jako środowisko postindustrialne. Główne znaczenie odgrywają w nim takie gałęzie gospodarki jak: przemysł, usługi, bankowość i informatyka oraz media - stanowiące dotychczas głównie źródło przekazywania wiadomości. Media, w dobie rozwoju społeczeństwa ponowoczesnego, mają charakter masowy i pełnią - poza funkcją informacyjna, charakteryzującą je w latach wcześniejszych - również funkcję opiniotwórczą. Koncentrują się one nie tylko na samym przekazywaniu informacji o aktualnych wydarzeniach, lecz w dużej mierze także na atrakcyjności zawartych treści. W odróżnieniu od okresów poprzednich, społeczeństwo ma obecnie szansę samodzielnego sporządzania przekazów medialnych. Umożliwiają to narzędzia będące w posiadaniu większości osób, tj. wielofunkcyjny aparat telefoniczny, Internet czy przenośny komputer. Obecnie, aby utworzyć własny kanał informacyjny, wystarczy założyć profil w mediach społecznościowych, gdzie każdy użytkownik może prezentować samodzielnie przygotowane materiały medialne o dowolnej tematyce. Takie zajęcie staje się również dla wielu osób sposobem zdobywania popularności, a coraz częściej i źródłem dochodu. Zauważalnym zjawiskiem w sferze zawodowej jest odejście od wykonywania wyuczonych profesji, na rzecz pracy mobilnej, często zdalnej i projektowej, co również wiąże się z przemianą współczesnej klasy średniej. Domeną tak funkcjonującego społeczeństwa zachodniego jest rezygnacja z dotychczasowego ascetycznego podejścia, na rzecz postaw hedonistycznych, charakteryzujących się wyraźnym wzrostem konsumpcjonizmu i korzystaniem z przyjemności jako formy wynagrodzenia za ciężką pracę. Jednocześnie obserwuje się osłabienie trwałych form religijnych, narodowych i klasowych. Grupą wyraźnie charakterystyczną ze względu na prestiż zawodowy, wysokość osiąganych zarobków oraz charakter pracy są przedstawiciele sportu zawodowego, ze szczególnym uwzględnieniem piłkarzy nożnych.

Sport we współczesnym społeczeństwie traktowany jest głównie jako element rozrywki. Badania przeprowadzone przez CBOS (2018) ukazały, że najwyżej notowanymi przez Polaków dyscyplinami sa: jazda na rowerze - preferowana przez 51\% przedstawicieli społeczeństwa; pływanie uprawiane przez $28 \%$ osób oraz turystyka górska praktykowana przez 16\% badanych. Piłka nożna, powszechnie uznawana za 
najpopularniejszą dyscyplinę sportu w Polsce, klasyfikuje się dopiero na miejscu 7, ponieważ wskazało ją 14\% ankietowanych. Zgodnie z powyższymi badaniami, Polacy wybierają ten sport ze względu na przyjemność i zamiłowanie (56\%), lub motywując swój wybór sposobem spędzania czasu w gronie znajomych (44\%). Należy zwrócić jednak uwagę, że aż $68 \%$ osób deklaruje, iż tę formę aktywności fizycznej wykonuje sporadycznie. Dane te zdają się potwierdzać tezę, że uprawianie sportu staje się domeną ludzi dorosłych, którzy traktują aktywność ruchową jako element rekreacji bądź też podtrzymywania kondycji. Popularność gier komputerowych, powszechny dostęp do Internetu, telewizji i wielofunkcyjnych telefonów komórkowych sprawiaja, że tradycyjne formy zabawy $\mathrm{w}$ ruchu - pośród których dominowały podwórkowe rozgrywki, np. w piłkę nożną - znajdują coraz mniejsze uznanie wśród nastolatków.

Stan ten znacząco odbiega od zainteresowania piłką nożną w dawnych latach. Przykładami obrazującymi tę różnicę są wspomnienia dwóch absolwentów kursu trenerskiego w Akademii Wychowania Fizycznego im. Józefa Piłsudskiego w Warszawie. Późniejszy selekcjoner reprezentacji Polski i jedna z ikon krajowej myśli szkoleniowej - Kazimierz Górski, wspominał, że dostęp do sprzętu sportowego, nawet tak podstawowego jak piłka do gry, był utrudniony dla robotniczej społeczności Bogdanówki. Pomimo tego, jako dziecko, grał w piłkę nożną przy każdej możliwej okazji (Ławecki, 2010). Z podobnym zapałem o początkach swojej piłkarskiej pasji wypowiada się trener Andrzej Strejlau, wspominając czasy młodości na warszawskich Bielanach. Podkreśla on ogromną pasję do gry w piłkę nożna, która w owym czasie była przede wszystkim zabawa, grą podwórkową. W 1954 roku talent Andrzeja Strejlaua został dostrzeżony przez trenera Jerzego Talagę, poszukującego zawodników do drużyny juniorów AZS-AWF wśród lokalnej społeczności (Chromik, 2018).

Wspomnienia dotyczące dwóch trenerów, mogą wydać się zaskakujące dla współczesnego pokolenia dorastających piłkarzy. Przeżywając swoją młodość bez dostępu do Internetu, multimediów i gier komputerowych, szukali rozrywki w sporcie. Jedną z najpopularniejszych rozrywek była piłka nożna, traktowana przez chłopców jako podstawowa podwórkowa zabawa i sposób spędzania czasu z przyjaciółmi. Podczas takich podwórkowych rozgrywek w naturalny sposób wyrabiał się charakter, młodzi ludzie uczyli się też funkcjonowania w grupie oraz zdrowej rywalizacji. To tu wyłaniali się liderzy, a czynnikiem wpływającym na to były prezentowane kompetencje sportowe. Jak zauważył trener Strejlau, wypracowanie pierwszych umiejętności technicznych oraz naturalna rywalizacja i socjalizacja w grupie sprawiały, że $\mathrm{w}$ warunkach zabawy dokonywał się pierwszy proces selekcji. Obecnie, gdy piłka młodzieżowa coraz bardziej ogranicza się do zorganizowanych form gry w komercyjnych akademiach piłkarskich, ponownie zwracana jest uwaga na znaczenie elementu zabawy jako właściwego kierunku kształcenia zawodników piłki nożnej na podstawowym poziomie.

Niezależnie jednak od zmian zachodzących w kształceniu młodych zawodników, piłka nożna pozostaje wciąż popularna, głównie ze względów widowiskowych. Ilość klubów sportowych prowadzących szkolenie młodzieży jest w Polsce wciąż bardzo duża. Polski Związek Piłki Nożnej, w celu zwiększenia profesjonalizacji pracy z najmłodszymi sportowcami wprowadził na przełomie 2018 i 2019 roku program certyfikacji szkółek (PZPN, 2019a). Do programu zgłosiło się 1197 ośrodków, z których skla- 
syfikowano 1080, a 117 odrzucono (PZPN, 2019b). Statystyki te pokazuja że droga od piłki młodzieżowej do występów w ramach drużyn zawodowych, wiąże się z bardzo długim procesem, co czyni zawód piłkarza profesją o charakterze elitarnym.

Jednak zawód piłkarza, choć powszechnie uznawany za ceniony, szanowany i cechujący się dużym poziomem popularności, nie zostaje ujęty w klasyfikacji zawodów prestiżowych. Powodem takiego stanu rzeczy może być fakt, że - pomimo wysokiej pozycji i uznania społecznego - nie został on powszechnie uznany za profesję. Jak wskazuje Michał Lenartowicz (2019), mówiąc o sportach należy zwrócić uwagę głównie na połączenia z dotychczas uznanymi zawodami. Statystyki rozpoznają jako profesję menadżera sportu, organizatora imprez o charakterze sportowym, lekarza czy fizjoterapeutę o specjalizacji sportowej. Nie ujmuje się tu jednak czynnego zawodnika, który to zawód występuje z kolei w klasyfikacji Ministerstwa Pracy i Polityki Społecznej oraz w klasyfikacji w zakresie pośrednictwa pracy i poradnictwa zawodowego oraz szkolenia zawodowego sportowcy (jako „zawodnicy dyscypliny sportu”). Czynni zawodnicy pojawiają się tu w grupie „sportowców, trenerów i zawodów pokrewnych" pod numerem 342 (podgrupa "sportowcy i dżokeje”, poz. 3421). W polskiej klasyfikacji zawodów jest także m.in. instruktor i trener sportu, sędzia sportowy (poz. 3422) oraz nauczyciel wychowania fizycznego. Za wskazanym stanowiskiem przemawia również sama charakterystyka zawodu sportowca, $\mathrm{z}$ karierą skokowa, uzależnioną od osiagganych wyników. Spektakularne sukcesy pozwalają na awans sportowy. Porażki z kolei mogą znacząco obniżyć renomę danego gracza. Ponadto zawodnik musi w pełni angażować się $\mathrm{w}$ wykonywanie swojego zawodu. Wynika to z konieczności poświęcania czasu na doskonalenie własnych umiejętności sportowych, częste przeprowadzki podyktowane zmianami barw klubowych, bardzo dynamiczny rozwój kariery i stosunkowo szybki jej koniec przypadający na okres życia między 30 a 40 rokiem życia (Lenartowicz, 2019). Najbardziej uzdolnieni piłkarze - grający w najlepszych zespołach w swoich krajach, występujący w rozgrywkach Ligi Mistrzów czy Ligi Europy, rozgrywają mecze przeciętnie trzy razy w tygodniu. Okresy pomiędzy występami na boisku są natomiast przeznaczone na uczestnictwo w zgrupowaniach. Znikoma ilość dostępnego czasu wolnego, jest przez zawodników poświęcana na regenerację przed następnymi meczami. Powyższe uwarunkowania są często dużym utrudnieniem dla życia rodzinnego i prywatnych aspiracji, które stają się możliwe do zrealizowania dopiero po zakończeniu profesjonalnej kariery. Wraz z jej końcem zmniejsza się zazwyczaj poziom dochodów, wymuszając na graczu umiejętne zarządzanie środkami materialnymi $w$ trakcie czynnego uprawiania sportu. Biorąc zatem pod uwagę ilość wyrzeczeń i czasu poświęcanego na doskonalenie formy, zawód sportowca jest wynagradzany w postaci wysokich gratyfikacji.

Wskazane wyżej czynniki charakteryzujące zawód piłkarza sprawiaja, że do najwyższego poziomu dochodzi tylko znikoma ilość kandydatów. Ci zaś, którzy osiagają najwyższy szczebel kariery, cieszą się dużym poważaniem w społeczeństwie oraz wysokimi wynagrodzeniami. Przykładem takiego rozumienia prestiżu wynikającego z kariery sportowej, może być Robert Lewandowski, który - dzięki wybitnym osiągnięciom w piłce klubowej w barwach Bayernu Monachium oraz występom w reprezentacji Polski - uchodzi za wpływową postać wśród Polaków ciesząc się dużą rozpoznawalnością na świecie (Dziubiński, 2018).

Ogrody Nauk i Sztuk nR 2021 (11) 


\section{Proces SeleKCJi ZaWOdNiKóW JAKo ETAP PRzygotowania do SPORTU}

PROFESJONALNEgo

Proces dokonania wyboru zawodników do gry zawodowej jest długą droga przez którą młody człowiek przechodzi w środowisku rywalizacji sportowej, aspirując do grupy uprawiającej sport $\mathrm{w}$ ramach wychowania fizycznego, będaccego procesem kształtującym rozwój psychofizyczny dzieci i młodzieży. Szkolne zajęcia WF mogą bowiem stanowić dobrą podstawę do zainteresowania sportem i zachęcić ucznia, by aspirował do sportu profesjonalnego, rozumianego jako rodzaj wyczynowego sportu uprawianego w celach zarobkowych (Piłat, 2004). Piłkarze należący do tej grupy, stanowią grupę zawodników, którzy przeszli pełen proces szkolenia. Ich talent zidentyfikowano i rozwinięto do tego stopnia, że zostali zakwalifikowani do grupy zawodników uzyskujących ze swojej profesji wysokie gratyfikacje, a także wysoki prestiż społeczny wynikający z faktu wykonywania zawodu piłkarza.

W celu identyfikacji i rozwoju predyspozycji sportowych młodego człowieka, tworzone są odpowiednie jednostki umożliwiające ten proces. Można do nich zaliczyć klubowe akademie piłkarskie, ale także klasy i szkoły sportowe tworzone w oddziałach szkół podstawowych i licealnych, jak również Szkoły Mistrzostwa Sportowego, kształtujące predyspozycje dzieci i młodzieży przynajmniej w jednej dyscyplinie. Formują one zawodników o podobnym poziomie umiejętności co najmniej w jednym oddziale i trzech klasach danego poziomu edukacji szkolnej (Piłat, 2004).

Rozwój młodego sportowca podlega wielu zmiennym, składającym się na proces selekcji, który można podzielić na cztery etapy. Pierwszym z nich jest preselekcja, polegająca na obserwacji dzieci w najmłodszym wieku pod kątem ich predyspozycji sportowych, przed rozpoczęciem szkolenia. Kolejny etap to selekcja wstępna, kierujacca dzieci do wszechstronnego szkolenia bez jednoznacznego przydziału do dyscypliny. Etap ten jest połączony z wyszukiwaniem dzieci o szczególnych uzdolnieniach ruchowych. Trzeci etap to selekcja właściwa, czyli wybór najbardziej uzdolnionych jednostek, wyróżniających się szczególnymi predyspozycjami sprawnościowymi, anatomicznymi i funkcjonalnymi. Odbywa się ona po 2-4 latach szkolenia wszechstronnego. Ostatnim, czwartym etapem jest selekcja specjalistyczna, dążąca do precyzyjnego i szczegółowego określenia predyspozycji i wymogów treningu. Selekcja ta dotyczy już konkretnej dyscypliny sportu (Piłat, 2004). Równolegle do procesu selekcji przebiega proces treningowy, który można podzielić na trzy etapy. Pierwszym $\mathrm{z}$ nich jest etap treningu wszechstronnego, przypadający na okres między 10 a 13 rokiem życia. Okres ten w życiu młodego zawodnika jest czasem wzmożonego rozwoju biologicznego i psychicznego, zmierzającego do ról w życiu dorosłym. Drugi etap to trening ukierunkowany, który plasuje się między 14 a 17 rokiem życia. Na tym etapie ulegają zmianie obciążenia treningowe wśród zawodników, stając się bardziej intensywnymi. Ze względu na proces dorastania młodego piłkarza, zmieniają się także interakcje na linii zawodnik-trener. Wymuszają one na szkoleniowcu poszukiwanie właściwych metod wychowawczych i treningowych, które byłyby dla podopiecznego nie tylko właściwym elementem rozwoju sportowego, lecz także motywowałyby do dalszej pracy. Trzecim z etapów jest trening specjalistyczny, podejmowany przez graczy, których - w wyniku dotychczasowego procesu selekcji - określono jako graczy dysponujących właściwymi kompetencjami koniecznymi do profesjonalnego 
uprawiania sportu. Wysoki poziom umiejętności nie oznacza jednak zakończenia procesu edukacji gracza. Na tym etapie bowiem kształtuje się w nim większą świadomość własnych umiejętności w procesie współpracy partnerskiej. Interakcja na linii zawodnik - trener, przybiera formę dyskusji i wspólnej oceny gry, jak również aktualnych umiejętności i potencjału zawodnika. W efekcie prowadzi to do intelektualizacji procesu treningowego i zachowania, także w duchu fair play (Żukowski, 2013a).

Należy więc stwierdzić, że piłkarz - od chwili pierwszego kontaktu z aktywnością fizyczną $\mathrm{w}$ okresie dziecięcym do momentu znalezienia się $\mathrm{w}$ gronie profesjonalnych sportowców - przechodzi przez bardzo złożony proces, podczas którego jest bacznie obserwowany pod kątem szeroko rozumianych predyspozycji. Fakt ten sprawia, że niewielu zawodników trafia do wąskiego grona zawodowców. Dla zobrazowania powyższych zależności można przytoczyć badania przeprowadzone przez Rasmusa Ankersena, działacza duńskiej drużyny FC Midtjylland, oraz autora popularnej książki Kopalnie Talentów. W swojej publikacji podejmuje on kwestie związane z identyfikacją i rozwojem talentów, prezentując badania przeprowadzone w Brazylii na lokalnej grupie młodzieży trenującej piłkę nożną i aspirującej do gry w barwach popularnego krajowego zespołu Cruzeiro. R. Ankersen zauważa, że - spośród 4000 graczy kwalifikowanych do gry w kategorii do lat 15 - tylko jeden zawodnik przechodzi selekcję pozytywnie. Do starszych drużyn natomiast aspiruje liczba 126000 graczy, z czego pozytywny wynik selekcji osiaga jeden z nich (Ankersen, 2018). Można założyć, że główną motywacją tak dużej liczby młodych Brazylijczyków aspirujących do profesjonalnego uprawiania sportu jest nie tylko pasja do uprawianej dyscypliny. Tak wysokie zainteresowanie młodzieży piłkarstwem profesjonalnym wynika również z nadziei na opisane wcześniej korzyści materialne i społeczne związane z tym zawodem. Tezę tę zdaje się potwierdzać fakt, że aż 95\% brazylijskich zawodników uprawiających piłkę nożną zarobkowo, pochodzi z najbiedniejszych środowisk, w których sukces sportowy i wiążące się z nim gratyfikacje, pozwalają na poprawę statusu materialnego rodziny i uniknięcie drogi przestępczej. Zjawisko to rodzi pytanie o sposób rozwoju talentu piłkarskiego. Powoduje on bowiem dużą różnicę $\mathrm{w}$ ilości zawodników rozpoczynających proces selekcji oraz tych, którzy ją pomyślnie kończą. R. Ankersen podejmując to zagadnienie podkreśla, że do osiągnięcia wybitnego poziomu w danej dyscyplinie, wymagane jest powtarzanie danego ćwiczenia przynajmniej przez 10000 godzin w celu osiągnięcia bezbłędnego wykonania i zautomatyzowania (Ankersen, 2018). Motywacja zarobkowa połączona z marzeniami o osiągnięciu prestiżu społecznego swoich idoli, jak również codzienne zabawy z piłką pośród faweli sprawiaja, że Brazylia może szczycić się dużą grupą wysoce wykwalifikowanych zawodników, pozwalających na stałe utrzymanie najwyższego poziomu krajowej reprezentacji.

Jak wyżej wskazano, spośród graczy, którzy rozpoczęli proces szkolenia, niewielu zostaje zakwalifikowanych do najwyższego poziomu gry. Wraz z kolejnymi etapami selekcji liczba graczy maleje. Zwiększa się także poziom rywalizacji między zawodnikami. Na etapie sportu zawodowego kluby mogą pozwolić sobie na poszerzenie grona kandydatów o piłkarzy występujących w innych klubach. W takich sytuacjach dochodzi do transferu zawodników. Do środowiska osób zajmujących się identyfikacją i selekcją zawodników graczy należy zaliczyć - oprócz trenerów dokonujących selekcji - piłkarskich skautów. Można ich scharakteryzować jako specjalistów potra- 
fiących na podstawie obserwacji ocenić wartość młodego zawodnika, zidentyfikować jego mocne i słabe strony, jak również przewidzieć jego dalszy rozwój. Rola skauta nie ogranicza się jedynie do odkrycia talentu, lecz obejmuje udział w całym procesie skautingu, aż do włączenia zawodnika do klubu (Pawlak, Smoleń, 2010). Skauci dokonują obserwacji umiejętności i potencjału zawodników zarówno z poziomu seniorskiego, jak i graczy młodzieżowych, aby jak najwcześniej zapewnić klubowi angaż zdolnego gracza. Najniższy wiek zawodników transferowanych wynosi z reguły 13-15 lat i uwarunkowany jest procesem edukacji oraz etapem rozwoju psychicznego. $\mathrm{W}$ tym okresie życia koniecznym jest bowiem przebywanie młodego gracza w gronie rodziny i w lokalnym środowisku. Gdy jednak zawodnik ukończy etap szkoły podstawowej, a jego poziom dojrzałości pozwoli na zmianę otoczenia, możliwym staje się przeprowadzenie transferu do innego klubu. Poprzez zapewnienie takiemu zawodnikowi właściwego środowiska do podnoszenia kwalifikacji i odpowiedniego poziomu rywalizacji sportowej, klub podejmuje starania o właściwe wykształcenie w zawodniku jak najlepszych umiejętności sportowych oraz predyspozycji mentalnych do profesjonalnego uprawiania piłki nożnej.

Kluczowym zagadnieniem, poruszanym już wcześniej, jest stworzenie odpowiedniego środowiska, pozwalającego na wzrost umiejętności. Podejmując tę tematykę należy najpierw pochylić się nad kwestią elementów kluczowych, podlegających ocenie aktualnych umiejętności i potencjału kandydata do profesjonalnej gry w piłkę nożną. Skaut oceniający umiejętności gracza - jego mocne i słabe strony oraz potencjał - ma za zadanie określić profil tego zawodnika tak, by umożliwić ocenę jego przydatności $\mathrm{w}$ danym klubie i maksymalnie przewidzieć jego dalszy rozwój. Zasadniczo proces ten odbywa się w zakresie czterech podstawowych aspektów, tj. taktycznym, fizycznym, technicznym i charakterologicznym (Pawlak, Smoleń, 2010). W aspekcie technicznym określa się przede wszystkim umiejętności indywidualne, przyjęcie i prowadzenie piłki, poprawność oddawanego strzału, drybling i wszystkie inne czynności, które należy kształtować w najmłodszych latach edukacji sportowej na etapie selekcji wstępnej. Aspekt taktyczny obejmuje przełożenie umiejętności indywidualnych na grę zespołowa, rozumienie specyfiki danej pozycji boiskowej, komunikację z drużyną grę bez piłki, ustawianie się na boisku, jak również wszystkie czynności pozwalające przełożyć własne umiejętności techniczne na dobro drużyny jako całości. Aspekt fizyczny, z racji uwarunkowań rozwoju fizycznego, kształtowany jest na późniejszych etapach formacji sportowej. Dotyczy on zdolności rozwinięcia nabytych wcześniej umiejętności technicznych i taktycznych w obszarze siły strzału, siły podania, dynamiki ruchu i rywalizacji boiskowej.

Zawodnik posiadający wysoce rozwinięte umiejętności sportowe, czyli predyspozycje techniczne, taktyczne i fizyczne, jest gotowy do podjęcia rywalizacji i do aspirowania do gry na profesjonalnym poziomie. Należy również przyjąć, że gracz o wysoce rozwiniętych walorach $w$ tych trzech obszarach, posiada umiejętności sportowe pozwalające mu na właściwy rozwój kariery. Istnieje jednak wielu graczy, którzy pomimo wysokich umiejętności i pokonania poszczególnych etapów selekcji, nie osiągnęli sukcesu, choć był on w ich przypadku przewidywany jako bardzo prawdopodobny. Wpływ na niepowodzenie w rozwoju talentu mógł mieć czwarty z czynników obserwacji gracza, tj. aspekt charakterologiczny. Jest on określany w arkuszach 
obserwacyjnych skautów mianem predyspozycji mentalnych i uznawany przez wielu ekspertów za najważniejszy. Aspekt charakterologiczny zawiera w sobie cechy związane z interakcjami społecznymi, jak również z uwarunkowaniami osobowościowymi, wynikającymi z procesu wychowania i z doświadczeń życiowych. Zalicza się tu również dojrzałość emocjonalną oraz gotowość do wykonywania zawodu sportowca - w tym gotowość do rywalizacji z zawodnikami o równie wysokim poziomie umiejętności sportowych. Do czynnika mentalnego zaliczyć można także poziom decyzyjności. Zbigniew Naglak określa ją jako umiejętność przetworzenia zamiarów na cel. Jest ona ściśle związaną z szybkością reakcji i przetwarzania informacji z zewnętrznego środowiska (Naglak, 2005).

\section{WSPÓŁCZESNY TRENER PIEKI NOŻNEJ W PROCESIE WYCHOWANIA MEODEGO GRACZA}

Powyższe refleksje ukazuja, że obecni piłkarze mogą posłużyć za przykład przemian następujących nie tylko wśród współczesnego społeczeństwa, lecz również w etosie współczesnego sportowca. Do czynników wpływających na te przemiany można zaliczyć coraz większą transformację samego środowiska piłkarstwa zawodowego i organizacji klubów. Obserwuje się wyraźny i znaczący wzrost środków finansowych pozyskiwanych przez kluby i federacje z zawieranych umów sponsorskich. Corocznie osiagane są nowe rekordy z tytułu transferów graczy, wprowadza się nowe technologie umożliwiające coraz dokładniejszą analizę wyników zawodnika. Wszystkie te czynniki - w świetle przemian następujących we współczesnym społeczeństwie - sprawiają że od graczy wymaga się coraz większego profesjonalizmu, dyspozycyjności i zaangażowania, wynagradzając jednocześnie ich pracę coraz wyższymi zarobkami.

Zawodnik, z perspektywy widza i biernego obserwatora rozgrywek, postrzegany jest przez pryzmat osiagganego rezultatu. Rezultat ten należy jednak postrzegać z perspektywy efektu końcowego, na który składają się wszelkie okoliczności wpływające na aktualną dyspozycję gracza. Można do nich zaliczyć uwarunkowania procesu treningowego, jak również czynniki związane bezpośrednio z aspektami gry i przygotowania sportowego. Do równie ważnych uwarunkowań należą też kwestie związane z mentalnością gracza - jego problemami osobistymi, doświadczeniami życiowymi, motywacją czy predyspozycjami charakterologicznymi. $Z$ tego względu, $\mathrm{w}$ procesie rozwoju kompetencji zawodnika, bardzo istotną rolę zyskuje środowisko, w którym kształci on kompetencje sportowe i osobowościowe konieczne do profesjonalnego uprawiania dyscypliny. Takie spojrzenie na uczestnictwo w profesjonalnym uprawianiu piłki nożnej prowadzi do refleksji nad tematyką wychowania nowych pokoleń piłkarzy. Rozważyć należy zagadnienia dotyczące współczesnego rozumienia selekcji zawodników, u podstaw której leży wymiar pedagogiczny, polegający na wychowaniu do sportu. Ono bowiem stanowi cel, na którego realizację składają się działania zmierzające ku właściwemu formowaniu młodego gracza (Nowocień, 2013). Z powyższych rozważań wynika także, że przejście z etapu uprawiania piłki młodzieżowej do sportu seniorskiego, jest długotrwałym procesem, w którym - poza samymi predyspozycjami - ważnym czynnikiem jest determinacja do osiągnięcia sukcesu i podjęcia rywalizacji.

Piłka nożna jako sport o zasięgu globalnym, wzbudzający zainteresowanie większości młodych chłopców, zalicza się do dyscyplin, w których proces selekcji obejmuje

Ogrody Nauk i Sztuk nR 2021 (11) 
znacznie wyższą liczbę kandydatów aspirujących do poziomu profesjonalnego niż ma to miejsce w przypadku innych dyscyplin. $Z$ tego względu zawodnik, by umiejętnie radzić sobie z presją i konkurencją, powinien na każdym z etapów swojego rozwoju sportowego, rozwijać się również osobowościowo. Celem rozwoju w tym obszarze jest wyzwalanie w młodym zawodniku wartości, które w dobie globalizacji posiadają szczególne znaczenie. Należą do nich wolność - rozumiana jako możność dokonywania wyboru i samodzielnego podejmowania decyzji; godność będąca wyrazem postępowania $\mathrm{w}$ stosunkach międzyludzkich oraz odpowiedzialność - obejmująca stosunek do podejmowanych działań i ich efektów (Nowocień, 2019). W procesie kształtowania młodego sportowca jako osoby istotną rolę odgrywa trener, którego zadaniem jest nie tylko wydawanie komend dotyczących kolejnych ćwiczeń. Jest on również pedagogiem, mającym znaczący wpływ na kształtowanie osobowości młodego sportowca. $Z$ tego względu słusznym zdaje się być wyraźne odróżnianie sportu dzieci i młodzieży od tego, który uprawiają ukształtowani, dorośli gracze profesjonalni. Do opisania ich profesji właściwymi zdają się być określenia mówiące o rywalizacji czy grze, zmierzającej do osiągnięcia jak najlepszego wyniku. Sport młodzieżowy, w odróżnieniu od specyfiki rozgrywek profesjonalnych, winien być postrzegany jako proces pedagogiczny, zmierzający ku właściwemu przygotowaniu do podejmowania rywalizacji. W procesie tym samo zwyciężanie zastąpione jest nauką do zwyciężania, a stanowiąca cel kariera jest dopiero zarządzaniem talentami - rozumianym jako proces obejmujący wielopłaszczyznową selekcję, w której kluczowym elementem rozwoju jest poziom zawodników (Seweryniak, Panfil, 2014). Sport młodzieżowy należy zatem traktować jako proces pedagogiczny, przygotowujący do profesjonalnego uprawiania sportu, a za talent sportowy należy uznać predyspozycje techniczne, taktyczne, motoryczne a także mentalne, które zostały zweryfikowane $\mathrm{w}$ wyniku selekcji i poprzez rywalizację.

Proces rozwoju zawodnika przebiega w środowisku sprzyjającym właściwemu kształtowaniu młodzieży - zarówno pod kątem umiejętności technicznych, jak i właściwych postaw. Środowisko to jest grupą osób, którą stanowią rodzice, nauczyciel, przedstawiciel władz klubowych, osoby związane z samorządem terytorialnym odpowiedzialnym za rozwój regionalnego sportu, a także trener (Panfil, 2012). Ryszard Żukowski (2013a), podejmując tematykę treningu wyczynowego młodzieży w perspektywie wychowawczej i edukacyjnej, rozumie rolę trenera jako jeden z dwóch podmiotów w szkoleniu sportowym, posiadającym charakter pedagogiczny. Drugim podmiotem jest osoba zawodnika.

Na przestrzeni ostatnich dekad charakter i specyfika pracy trenera uległy dużym przeobrażeniom. Jeszcze w połowie XX wieku trener posiadał funkcje ściśle skupione wokół samego treningu sportowego, tj. opracowanie założeń taktycznych, dobór metod podnoszenia umiejętności i prowadzenie zespołu podczas spotkań (Nowocień, 2013). Uwarunkowania cechujące nowe społeczeństwo, wyzwania stojące przed współczesnymi sportowcami, jak również profesjonalizacja zawodów i zauważalny wzrost samoświadomości trenerów, miały wyraźny wpływ na przeobrażenie i charakter pracy trenera. Od trenera wymaga się obecnie również umiejętności zarządzania rozwojem zawodników także w sferze osobowości. Proces ten, jak dalej określa R. Żukowski, przebiega w określonych warunkach społecznych dzieci i młodzieży, wy- 
magając właściwego i sprzyjającego rozwojowi środowiska. Środowisko to stanowią kluby, akademie, związki sportowe i wszelkie inicjatywy organizujące rozgrywki. Powinny one współtworzyć jeden system zabezpieczający sprawny i efektywny udział osób, organizacji, instytucji - zarówno samorządowych, jak i państwowych w realizacji wszystkich celów służących rozwojowi dzieci i młodzieży. Rozwój ten dotyczy nie tylko sprawności sportowej, lecz powinien odbywać się również $\mathrm{w}$ aspekcie edukacyjnym, wychowawczym a także w procesie interakcji społecznych, mając na celu spowodowanie zmian w osobowości gracza. W świetle rozważań R. Żukowskiego należy uznać, że najsilniejszy wpływ na przebieg procesu wychowawczego współczesnej młodzieży uprawiającej sport pochodzi z trzech źródeł. Pierwszym z nich jest oddziaływanie osób i instytucji, drugim natomiast system wychowania równoległego, przez który należy rozumieć media (m.in. prasa, telewizja, radio, publicystyka, ale także zyskujące współcześnie na znaczeniu media społecznościowe) i kulturę (teatr, kino, książki). Trzecim źródłem wpływu jest praca nad samodoskonaleniem w aspekcie umiejętności (Żukowski, 2013a i b).

Powyższe treści ukazują zatem, że współczesna młodzież aspirująca do profesjonalnego uprawiania sportu, powinna wzrastać w ściśle określonych warunkach, w których znaczący wpływ ma środowisko i bodźce zewnętrzne, czyli treści, po które sięga młodzież. Przytoczone wyżej czynniki oraz charakterystyka współczesnego społeczeństwa dowodza, że przed trenerem pracującym ze współczesną młodzieżą sportową stoi szereg wyzwań. Z tego względu trener jako element środowiska wspierającego rozwój gracza i bezpośrednio wpływający na jego postęp, musi dysponować odpowiednimi kompetencjami dotyczącymi swojego zawodu. Powinny one zawierać przygotowanie psychologiczne, pedagogiczne, metodyczne oraz etyczno-kulturowe. To właśnie kompetencje pedagogiczne, wraz z wyrównanym poziomem kompetencji przedmiotowych (kierunkowych), mają duży wpływ na sukces zawodowy w sporcie. Trener, ze względu na charakter swojej pracy, jak również towarzysząca jej misję i ogromną odpowiedzialność za wychowanie młodzieży, powinien mieć świadomość znaczenia swojej pracy. Winien dbać o wysoki poziom kompetencji i stałego podnoszenia kwalifikacji, które powinny opierać się na modelu partnerstwa, interakcji i wzajemnym szacunku. Trener jest osobą sprawującą pieczę nad rozwojem swoich podopiecznych, $\mathrm{z}$ tego względu powinien być świadomym nie tylko możliwych problemów i wyzwań współczesnej młodzieży, lecz także umiejętnie nad nimi panować i kierować ku ich właściwemu rozumieniu i rozwiązaniu. Musi on także zwracać uwagę na indywidualne podejście do zawodników, uwzględniając dynamikę grupy i dbałość o sprawiedliwe traktowanie poszczególnych graczy. Stosowany przez niego model sankcjonowania zachowań powinien przynosić pozytywne skutki nie tylko w przypadku pojedynczego zawodnika, lecz i całej grupy. $Z$ tego powodu, pośród kluczowych kompetencji trenera, można wyróżnić współdziałanie i umiejętności komunikacyjne. Wyrażają się one w otwartości do prowadzenia dialogu, odpowiednim komunikowaniu uczuć, akceptacji kodu językowego i umiejętności panowania nad mową ciała. Dobrego trenera powinna wyróżniać także skuteczność w planowaniu i właściwej realizacji założonego programu szkoleniowego wpisanego nie tylko $\mathrm{w}$ daną jednostkę treningowa, lecz także w cały cykl. Trener poza kompetencjami komunikacyjnymi, osobowościowymi i właściwym zarząadzaniem planem rozwoju 
sportowego, powinien także dbać o pogłębianie wiedzy, kształcenie się i korzystanie z nowych źródeł informacji. Wskazanym jest tworzenie autorskich programów treningowych, nawiązywanie współpracy z innymi trenerami, dbałość o pozyskiwanie treści naukowych, jak również znajomość języka obcego (Żukowski, 2013b).

Powyższe refleksje wyraźnie ukazują że zarówno trener, jak i gracz są podmiotami w zachodzącym procesie pedagogicznym. Stwierdzenie to koresponduje z tezą Z. Naglaka (2005), który poszerza powyższą myśl, twierdząc, że piłka nożna - jako dyscyplina skupiająca więcej niż trzech graczy - jest grą wielopodmiotową. W drużynie piłkarskiej, poza jedenastoma zawodnikami znajdującymi się w jednym momencie na boisku, należy uwzględnić pozostałych graczy, którzy pełnią funkcję rezerwowych a także zawodników znajdujących się poza kadrą meczową. Każdy z nich posiada swoje indywidualne cechy, na które składają się umiejętności techniczne oraz cechy osobowościowo-charakterologiczne. Proces treningowy, jak również rywalizacja połączona ze wspólnym dążeniem do osiągnięcia korzystnego rezultatu sprawiaja że formacja pedagogiczna w przypadku piłki nożnej zawiera nie tylko jedną relację na linii trener-zawodnik. Zostaje ona poszerzona o relacje między wszystkimi zawodnikami wchodzącymi w skład zespołu oraz trenerem i sztabem szkoleniowym, stanowiąc $w$ ten sposób bardzo różnorodny zbiór osobowości.

W tym kontekście należy zwrócić szczególną uwagę na rywalizację w piłce nożnej jako na czynnik determinujący selekcję. Celem sportu klasyfikowanego są wyniki uzyskane w rezultacie współzawodnictwa. Jednocześnie należy wyjaśnić, że jako sport klasyfikowany rozumie się działalność człowieka ukierunkowaną na kształtowanie osobowości oraz zależnej od czynników płci i wieku doskonałości psychicznej, fizycznej i motorycznej, umożliwiającej osiąganie sukcesów sportowych. Trzeba więc stwierdzić za Z. Naglakiem, że celem sportu samym w sobie jest dążenie do doskonałości i przekraczanie stawianych sobie barier, a nie sam proces rywalizacji (Naglak, 1999). Zawodnik zatem powinien w pierwszej kolejności dbać o swój rozwój, właściwe podnoszenie posiadanych umiejętności i o samoświadomość osobistych zdolności i ograniczeń. Wówczas prezentowany poziom będzie determinował rozwój drużyny jako całości stanowiącej sumę indywidualnego poziomu sprawności wszystkich zawodników. Wtedy drużyna osiągać będzie lepsze rezultaty. $Z$ tego względu grę w piłkę nożną należy rozumieć jako grę zespołowa, której podstawą są umiejętności indywidualne poszczególnych graczy. Trener, jako osoba zarządzająca dynamiką zespołu, powinien posiadać zdolność właściwego zarządzania grupą zarówno w dziedzinie doboru metod treningowych, jak i właściwego zarząadzania relacjami w zespole. Odbywa się to poprzez indywidualne podejście do każdego zawodnika i odpowiednie pobudzanie do rywalizacji, przy jednoczesnym zachowaniu ducha współpracy pomiędzy graczami. Taka postawa prowadzić będzie do właściwego nastawienia graczy do walki sportowej, podnoszenia kompetencji pojedynczych zawodników i odpowiedniego rozumienia rywalizacji pomiędzy nimi. Trener, powołując się na humanistyczne treści wychowania, jak również wartości przekazywane w procesie pedagogicznym, odwołuje się do sfery uczuć swojego zawodnika, wywołując w nim właściwe nastawienie do pracy sportowej (Naglak, 1999).

Innym, wyjątkowo ważnym czynnikiem pracy trenera, jest jego postawa moralna. Gracze w młodym wieku, często spędzający na grze w piłkę nożną większość swojego 
czasu wolnego, traktują osobę trenera jako szczególny autorytet i wzór do naśladowania. Aspekt ten zyskuje na znaczeniu w świetle aktualnych przemian, jakie mają miejsce w środowisku sportu młodzieżowego, gdzie - jak wcześniej wskazano - coraz częściej dochodzi do transferu zawodników w młodym wieku. Gracz zmieniający dotychczasowe środowisko, trafia do nowego miasta, zmieniając otoczenie, grono znajomych i pozostawiając swoich rodziców z dala od aktualnego miejsca pobytu. Sytuacja ta sprawia, że znaczenie osoby trenera jeszcze bardziej wzrasta. W pewnym stopniu przejmuje on bardzo odpowiedzialne funkcje wychowawcze, często zastępując osobę rodzica. Dlatego bardzo istotną cechą trenera powinno być wykazywanie się samoświadomościa, rozumianą jako wiarygodność w oczach samego siebie oraz wychowanków i właściwie rozumianej miłości do wychowanków (Ługowska, 2015). Inną cechą niezbędną do wykonywania zawodu trenera, jest wykazywanie się właściwą postawą moralną. Trener powinien dawać odpowiedni przykład swoim podopiecznym, którzy postrzegają go jako autorytet i osobę godną naśladowania. Powinien mieć również świadomość, że jego zachowania będą nie tylko zauważalne przez młodzież, ale także naśladowane i powielane w późniejszych etapach rozwoju (Nowocień, 2013).

Trener, jako istotny element środowiska wpływającego na rozwój piłkarza, podlega ciągłej ocenie. Dokonują jej zarówno sami piłkarze, postrzegający go jako mentora i wzór do naśladowania, lecz również rodzice, którzy zezwolili na przeniesienie dziecka w nowe środowisko, powierzając dalszy rozwój swojego dziecka konkretnej instytucji jaką jest dany klub sportowy. W związku z tym, trener jest również oceniany przez wewnętrzne środowisko, w którym pracuje. Pion sportowy, na czele z dyrektorem, koordynatorem klubowej akademii czy działaczami klubowymi, dokonuje wizytacji i oceny pracy szkoleniowca oraz osiagganych przez niego efektów. Zgodnie z uchwałą nr IV/63 z dnia 20 kwietnia 2017 zarządu Polskiego Związku Piłki Nożnej, każdy z trenerów posiada obowiązek podnoszenia swoich kompetencji i dalszego kształcenia. W Polsce licencje dla trenerów piłki nożnej wystawiane są na okres maksymalnie trzech lat, a ich warunkiem jest pozytywne zaliczenie kursów (Rozdz. IV, Art. 16, Pkt. 2) oraz udział w konferencjach trenerskich certyfikowanych przez PZPN w zakresie minimum 15 godzin w ciagu trzech lat. Innym wymogiem jest brak obostrzeń prawnych udokumentowanych wyciagiem z Krajowego Rejestru Karnego za okres pół roku oraz poświadczenia braku wszczęcia postępowania dyscyplinarnego także w aspekcie korupcji w sporcie (Rozdz. III, Art. 6). Regulacje w zakresie licencjonowania trenerów przez Federację wymagają od kandydatów oraz aktualnie pracujących trenerów podnoszenia umiejętności oraz zachowania postaw moralnych, które nie będą budziły wątpliwości co do etyczności wykonywanej pracy. Regulacje te pozwalają jednocześnie na prowadzenie zajęć $\mathrm{z}$ zawodnikami jako wzór postępowania etycznego. Trener powinien być więc osobą świadomą konsekwencji podejmowanych przez siebie działań. Powinien on pamiętać jednocześnie o tym, by w pracy z młodzieżą umiejętnie postrzegać wynik sportowy jako element wychowawczy - zarówno w przypadku zwycięstwa, jak i porażki. Trener winien dawać wzór do naśladowania swoim podopiecznym, obierając sobie za cel przedkładanie szacunku ze strony zawodników ponad popularność. Powinien podkreślać wagę umiejętności sportowych i charakteru oraz ciężko pracować, jednocześnie lubiąc swoje zajęcie (Migasiewicz, Kurzawski, Paliga, 2013).

Ogrody Nauk i Sztuk nR 2021 (11) 
Powyższe rozważania wskazują na wzrost znaczenia roli trenera w procesie kształtowania przyszłych pokoleń zarówno pod kątem sportowym, jak i osobowościowym. Wyzwaniem stojącym przed współczesnymi trenerami, jest uświadomienie sobie bardzo dużej odpowiedzialności wynikającej z faktu aktywnego uczestnictwa $\mathrm{w}$ procesie pedagogicznym. Współczesna rola trenera młodzieży nie ma na celu osiagnnięcia wysokiego wyniku sportowego, który staje się celem dopiero na poziomie sportu profesjonalnego osób dorosłych. Sukces w sporcie młodzieżowym należy mierzyć ilością absolwentów, którzy po odbyciu procesu selekcji, wykazują się wysokim poziomem umiejętności sportowych oraz godnymi uznania postawami moralnymi. W szerokiej dyskusji prowadzonej przez publicystów i środowiska zainteresowane szkoleniem młodzieży w Polsce, często zwraca się uwagę na konieczność podnoszenia kompetencji krajowych trenerów. Powinno się to odbywać w taki sposób, by ich wszechstronne umiejętności zapewniały wysoki standard przygotowania przyszłych pokoleń polskich zawodników, by dorównywali oni rówieśnikom z takich krajów jak Niemcy, Belgia, Holandia czy Chorwacja. W związku z tym, obok selekcji zawodników zarówno w procesie treningowym, jak i skautingowym, ważne jest dokonywanie podobnych procesów również w kontekście sztabu trenerskiego. Jednym z kluczowych warunków do stworzenia zawodnikowi właściwego środowiska, jest dokonanie w pierwszej kolejności selekcji trenerów. Dobór szkoleniowca o odpowiednich kompetencjach uwzględniających warsztat trenerski, przygotowanie pedagogiczne i psychologiczne, jak również umiejętności komunikacyjne i postawę moralna, może zapewnić wysoki poziom pracy z grupa zawodników. W dalszej zaś perspektywie przełoży się to na właściwe przeprowadzanie procesu selekcji oraz na rozwój zawodników. Zawodnicy, którzy nie będą posiadali predyspozycji do profesjonalnego uprawiania sportu, dzięki wszechstronnej formacji uzyskanej w klubach sportowych, wypracują postawy czyniące $\mathrm{z}$ nich dobrych, uczciwych, sumiennych i pracowitych ludzi.

\section{Bibliografia}

[1] Ankersen, R. (2018). Kopalnie Talentów - jak odkryć i rozwinąć talent u siebie i u innych. Kraków: SQN.

[2] CBOS (2018) Aktywność Fizyczna Polaków, Pobrane z: www.cbos.pl/SPISKOM.POL/2018/K_125_18.PDF.

[3] Chromik, J. (2018). On, Strejlau. Kraków: SQN.

[4] Dziubiński, Z. (2018). Geneza prestiżu sportu i sport jako źródło prestiżu. W: Z. Dziubiński, M. Lenartowicz (red.), Kultura Fizyczna a prestiż społeczny (ss. 15-35). Warszawa: AWF.

[5] Lenartowicz, M. (2019). Kariera sportowa i jej społeczne uwarunkowania. W: Z. Dziubiński, Z. Krawczyk, M. Lenartowicz M. (red.), Socjologia kultury fizycznej (ss. 327-341). Warszawa: AWF.

[6] Ławecki, T. (2010). Kazimierz Górski z piłka przez życie. Warszawa: Oficyna Wydawniczo-Poligraficzna Adam.

[7] Ługowska, D. (2015). Spójność i jedność. Osoba trenera a rozwój zawodników oraz drużyny sportowej. W: Kostorz J., Rogowska A. (red.), Osobowość trenera-wychowawcy w kulturze fizycznej (ss. 17-27). Opole: Politechnika Opolska.

[8] Migasiewicz, J., Kurzawski K., Paliga Z. (2013). Profesjonalizm i skuteczność trenera W: H. Sozański, J. Sadowski J. (red.), Trener - wczoraj, dziś i jutro (ss. 161-173). Biała Podlaska: AWF.

[9] Naglak, Z. (1999). Metodyka trenowania sportowca. Wrocław: Wydawnictwo AWF we Wrocławiu.

[10] Naglak, Z. (2005). Nauczanie i uczenie się wielopodmiotowej gry z piłka, T1: Kształcenie gracza na wstęnym etapie. Wrocław: Wydawnictwo AWF we Wrocławiu.

[11] Nowocień, J. (2013). Trener sportowy w perspektywie pedagogicznej. W: H. Sozański, J. Sadowsk, (red.), Trener wczoraj, dziś i jutro (ss. 101-118). Biała Podlaska: AWF.

[12] Nowocień, J. (2019). Pedagogika Sportu. Warszawa: AWF. 
[13] Panfil, Ł. (2012). Model wspierania talentów sportowych. W: M. Stor, T. Listwan T. (red), Sukces w zarządzaniu kadrami. Elastyczność w zarządzaniu kapitałem ludzkim. T1: Problemy zarzaddzo-ekonomiczne (ss. 326-336). Wrocław: Wydawnictwo Uniwersytetu Ekonomicznego we Wrocławiu.

[14] Pawlak, Z., Smoleń A. (2010). Skauting jako metoda poszukiwania talentów w piłce nożnej. W: J. Nowocień, J. Chełmecki (red.), Społeczno Edukacyjne oblicza wspótczesnego sportu i olimpizmu (ss. 99-108). Warszawa: AWF.

[15] Piłat, K. (2004). Elementy programowania sportu dzieci i młodzieży, t. 2. Warszawa: Wydawnictwa Polskiej Federacji Sportu Młodzieżowego.

[16] PZPN (2019a) Program certyfikacji szkótek pitkarskich. Pobrane z: www.media.laczynaspilka.pl/files/ pzphp/ZDg7MDA_dfadf14af3605bd5cbeb0ab77c5539bf.pdf.

[17] PZPN (2019b) Ponad tysiąc podmiotów zgłosito się do programu certyfikacji. Pobrane z: www.laczynaspilka.pl/pilka-dla-wszystkich/ponad-tysiac-podmiotow-zglosilo-sie-do-programu-certyfikacji1?fbclid=IwAR2HJ3J7imFJIK3SB8MUjddA7ZbgP1bVMxa3vJ5u-k9c0mPi-e_AYRM_bWw.

[18] Rymarczyk, P. (2019). Kultura fizyczna w społeczeństwie ponowoczesnym. W: Z. Dziubiński, Z. Krawczyk, M. Lenartowicz M. (red.), Socjologia kultury fizycznej (ss. 70-82). Warszawa: AWF

[19] Seweryniak, T., Panfil, Ł. (2014). Wybrane uwarunkowania rozwoju talentów sportowych, Prace Naukowe Uniwersytetu Ekonomicznego we Wroctawiu, nr 349 Sukces w zarzadzaniu kadrami Różnorodność w zarzadzaniu kapitałem ludzkim - podejścia, metody, narzędzia Problemy zarzadczo-ekonomiczne, s. 295-307.

[20] Żukowski, R. (2013a). Edukacyjne i wychowawcze aspekty treningu wyczynowego młodocianych. W: H. Sozański, J. Sadowski (red.), Trener wczoraj, dziś i jutro (ss. 33-45). Biała Podlaska: Akademia Wychowania Fizycznego Józefa Piłsudskiego, Biała Podlaska: AWF.

[21] Żukowski, R. (2013b). Standardy kompetencji pedagogicznych nauczycieli sportu - trenerów. W: H. Sozański, J. Sadowski (red.), Trener wczoraj, dziś i jutro (ss. 71-80). Biała Podlaska: Akademia Wychowania Fizycznego Józefa Piłsudskiego, Biała Podlaska: AWF. 